\title{
Proposed Action of Supply Chain Risk Mitigation Air Compressor Type L Unloading 1/4 HP Using Fuzzy - FMEA and Fuzzy - AHP Method in PT. XYZ
}

\author{
Dyah Lintang Trenggonowati ${ }^{1, *}$, Achmad Bahauddin ${ }^{1}$, Asep Ridwan ${ }^{1}$ and Yuyun Wulandari ${ }^{1}$ \\ ${ }^{I}$ Department of Industrial Engineering, Faculty of Engineering, Sultan Ageng Tirtayasa University, Jl. Jenderal Sudirman \\ KM.3, Banten 42435, Indonesia \\ *Corresponding Author: dyahlintang@untirta.ac.id
}

\section{Article history}

Received: 27.12.2020

Revised: 22.03 .2021

Accepted: 25.04.2021

DOI:10.31629/jit.v2i1.3204

\begin{abstract}
Established since the 80s, PT. XYZ is an air compressor manufacturing industry located in Tangerang, Indonesia. In the production process, the air compressor type L Unloading $1 / 4 \mathrm{HP}$ has a very complex supply chain network which makes the supply chain network activities experience obstacles in the form of risks or potential risks that can occur so that it can disrupt the smooth running of the supply chain activities of this air compressor. Yet, PT. XYZ has not maximally implemented risk mitigation actions in its supply chain. The purpose of this study is to propose a mitigation action against risk events that occur along the supply chain of air compressor type L Unloading 1/4 HP using the FFMEA (Fuzzy Failure Mode and Effect Analysis) and FAHP (Fuzzy Analytical Hierarchy Process) methods. Based on the research, there were 29 identified risk events with 5 priority risk events. And of the 5 priority risk events, each has 2 proposed mitigation actions per priority risk event.
\end{abstract}

Keywords: compressor, risk mitigation, supply chain, fuzzy methods

\section{Introduction}

Along with the development of the industry which has entered the industrial era 4.0 and the increasingly tighter competition between companies in creating quality and cheap products but also having fast delivery or distribution to consumers is a challenge for all companies. Seeing this condition, companies are required to have a well-coordinated supply chain system. In the flow of the supply chain, of course, many issues are highlighted starting from suppliers, production processes, delivery systems (logistics), to the end users. This is due to the intense competition that is currently occurring not only between companies but competition between supply chain networks or supply chains owned by each company.

The supply chain is a network of companies that jointly work to create and deliver a product into the hands of end users. The companies involved are suppliers, manufacturers, distributors, retailers or stores, as well as supporting companies such as logistics or shipping services [1].

All parties involved in the supply chain network work best with each other, especially in terms of services. However, in every activity in supply chain activities, of course, there will be opportunities for risk which of course can hinder supply chain flow activities starting from upstream suppliers, 
manufacturing, distribution, and end users. Supply chain risks can occur from upstream suppliers, factories, distribution, and downstream distributors, as well as consumers [2]. Risk is more associated with losses caused by events that may occur within a certain time. Risks cannot be avoided but can be minimized or eliminated by carrying out appropriate risk management. Usually, one risk cause can stimulate more than one risk event [3].

Established since the 80s, PT. XYZ is an air compressor manufacturing industry located in Tangerang and has branch companies in 5 (five) major cities in Indonesia. In this study, the air compressor supply chain network that will be carried out mitigation action is the supply chain network of air compressor type L Unloading $1 / 4 \mathrm{HP}$. The condition of the supply chain network for air compressor type L Unloading $1 / 4$ HP consists of suppliers (domestic and foreign), manufacturers, authorized distributors to end users. The large number of parties involved in the supply chain network raises the possibility of risks or potential risks that may occur along the flow of the supply chain. Among the risks that occur at the supplier's part, namely the late arrival of raw materials

However, from some of these risks, the risk that often occurs is the occurrence of air compressor product returns, where based on last year's data, the most product returns occurred in February 2018, totaling 20 products. Products that experience a return or return include damaged spare parts and an error in sending the type of air compressor to the distributor because this often happens, of course, causing the company to experience losses in terms of cost and time.

Based on the problems at PT. XYZ, the need to implement risk management in the supply chain system of PT XYZ to minimize risks and other potential risks that may occur in the flow of the supply chain (upstream to downstream) requires the application of risk management which is an effort to improve chain performance. supply gradually and continuously by addressing and preventing various risks that could potentially occur. The framework in supply chain risk management is carried out in five stages, namely determining objectives, risk identification, risk analysis, risk evaluation, and risk mitigation actions [4].

Methods that used in this study are FFMEA (Fuzzy Failure Mode and Effect Analysis) and FAHP (Fuzzy Analytic Hierarchy Process) methods. The selection of FFMEA and FAHP methods in this study, especially in the use of fuzzy in both methods, is to reduce the subjectivity of the final results of each method. FFMEA (Fuzzy Failure Mode and Effect Analysis) is a development of the FMEA method. FMEA (Failure Mode and Effect Analysis) is a method that considers risks related to failure modes, identifies and implements corrective action to resolve priority problems or problems [5].

The use of the fuzzy concept aims to emphasize the value desired by the respondent and to obtain the FRPN (Fuzzy Risk Priority Number) value. The FRPN (Fuzzy Risk Priority Number) value will determine the priority risk sequence or ranking of risk events which will later become input from the FAHP (Fuzzy Analytic Hierarchy Process).

The FAHP (Fuzzy Analytic Hierarchy Process) method will be used as a tool to mitigate priority risk events. AHP (Analytic Hierarchy Process) is a method that in principle looks for pairwise comparisons and calculates weighting factors to obtain relative priority results among the available alternatives [6].

The use of fuzzy in mitigation actions using the AHP (Analytic Hierarchy Process) method is to clarify or reinforce the weight vector value obtained from the results of the pairwise comparison questionnaire that has been filled in by the respondents.

It is important to carry out supply chain risk mitigation actions in order to minimize the risks that occur. The stages of activities in supply chain risk mitigation action consist of risk identification, risk analysis, risk evaluation, and risk mitigation. In addition, after this research is completed, it is hoped that it can increase the effectiveness of risk management in PT XYZ's supply chain system.

This study aims to carry out supply chain risk mitigation actions in order to minimize the risks that occur. The stages of activities in supply chain risk mitigation action consist of risk identification, risk analysis, risk evaluation, and risk mitigation. In addition, after this research is completed, it is hoped that it can increase the effectiveness of risk management in PT XYZ's supply chain system.

Carry out supply chain risk mitigation actions in order to minimize the risks that occur is an of important process in the industry. The stages of activities in supply chain risk mitigation action consist of risk identification, risk analysis, risk evaluation, and risk mitigation. The future prospective or this study is that the optimum proposal may improve the industrial process by increasing the effectiveness of risk management in PT XYZ's supply chain system. 


\section{Methods}

Research conducted at PT XYZ is a research with a quantitative approach. The research began with field observations, interviews with the supply chain system network of the air compressor type L Unloading 1/4HP at PT XYZ and referring to the supporting literature during the research, then direct and indirect data collection was carried out. In this study, the data required are primary data and secondary data. The primary data in this study were in the form of a questionnaire or questionnaire, namely the FMEA and AHP questionnaires. The FMEA questionnaire contains risk events while the AHP questionnaire contains the causes of risk events.

Risk events are obtained through literature studies, interviews with experts, and direct observation based on risk factors, namely supply risk, demand risk, manufacturing risk, distribution risk, product recovery risk, information risk, as well as $\mathrm{K} 3$ and Environmental risk. Furthermore, the data is processed using the Fuzzy-FMEA and Fuzzy-AHP methods.

Using the Fuzzy-FMEA method consists of several stages, namely [7]:

a. Determine the severity, occurrence, and detection value for each risk event.

b. Determine the fuzzy set input membership.

Table 1. Membership of Fuzzy Set Inputs

\begin{tabular}{|c|c|c|}
\hline Category & Curve Shape & Fuzzy Number \\
\hline Almost None & Triangles & $\left(\begin{array}{lll}0 & 0 & 2\end{array}\right)$ \\
\hline Low & Triangles & (1 2.54$)$ \\
\hline Medium & Triangles & $(355)$ \\
\hline High & Triangles & $(67.59)$ \\
\hline Very High & Triangles & $\left(\begin{array}{lll}8 & 10 & 10\end{array}\right)$ \\
\hline
\end{tabular}

c. Determining Fuzzy Set Output.

Table 2. Membership of Fuzzy Set Output

\begin{tabular}{ccc}
\hline Category & Curve Shape & Fuzzy Number \\
\hline None $(\mathrm{N})$ & Triangles & $(00200)$ \\
Very Low $(\mathrm{VL})$ & Triangles & $(100200300)$ \\
Low $(\mathrm{L})$ & Triangles & $(200300400)$ \\
High Low $(\mathrm{HL})$ & Triangles & $(300400500)$ \\
Low Medium $(\mathrm{LM})$ & Triangles & $(400500600)$ \\
Medium $(\mathrm{M})$ & Triangles & $(500600700)$ \\
High Medium & Triangles & $(600700800)$ \\
$(\mathrm{HM})$ & Triangles & $(700800900)$ \\
Low High $(\mathrm{LH})$ & Triangles & $(8009001000)$ \\
High $(\mathrm{H})$ & Triangles & $(90010001000)$ \\
Very High $(\mathrm{VH})$ & &
\end{tabular}

d. Fuzzy Rule Bases
Fuzzy rules bases are the rules used in the Fuzzy-FMEA method. Fuzzy rules bases consist of fuzzy input variables, namely severity, occurrence, and detection. In addition to the fuzzy input variables, fuzzy-RPN (Risk Priority Number) output is added using if-then rules. Rule bases consists of input variables totaling 125 rules $(5 \times 5 \times 5)$.

e. The defuzzification process

Defuzzification is the last process in the fuzzy method, which aims to reinforce the fuzzy-RPN (Fuzzy Risk Priority Number) value. The defuzzification process uses centeroid defuzzification in Matlab software, by entering the occurrence, severity, and detection values into the input field.

In addition to using the FFMEA method, this study used the FAHP. Here are the steps for using FAHP:

a. Create a hierarchical structure.

b. Create a pairwise comparison matrix

c. Normalization of the matrix (AX)

d. Calculate consistency

$$
\lambda_{\max }=\frac{\text { Priority weight }(A X)}{\text { Criteria weight }(X)}
$$

e. Calculating the consistency index (CI)

$$
\lambda_{\max }=\frac{\lambda \max -n}{n-1}
$$

f. Calculating the consistency ratio (CR)

where:

$$
C R=\frac{\mathrm{CI}}{\mathrm{RI}}
$$

$$
\begin{aligned}
& \mathrm{CR}=\text { Consistency Ratio } \\
& \mathrm{CI}=\text { Consistency Index } \\
& \mathrm{RI}=\text { Random Index }
\end{aligned}
$$

The random index (RI) is commonly used for each matrix order. The following is a table of RIs in each matrix order [8]:

Table 3. Random Index Table

\begin{tabular}{cc}
\hline $\mathbf{N}$ & $\mathbf{R I}$ \\
\hline 1 & 0 \\
2 & 0 \\
3 & 0.58 \\
4 & 0.9 \\
5 & 1.12 \\
6 & 1.24 \\
\hline
\end{tabular}




\begin{tabular}{cc}
\hline 7 & 1.32 \\
8 & 1.41 \\
9 & 1.45 \\
10 & 1.49 \\
11 & 1.51 \\
12 & 1.48 \\
13 & 1.56 \\
14 & 1.57 \\
15 & 1.59 \\
\hline
\end{tabular}

g. Converts matrix values into TFN (Triangular Fuzzy Number) values as follow.

Table 4. TFN (Triangular Fuzzy Number)

\begin{tabular}{ccc}
\hline $\begin{array}{c}\text { AHP } \\
\text { scale }\end{array}$ & Fuzzy Scale & Inverse Fuzzy Scale \\
\hline & $\begin{array}{c}1=(1,1,1)=\text { if the } \\
\text { diagonal is other than }(1,\end{array}$ \\
1 & $1,3)$ & $(1 / 3,1 / 1,1 / 1)$ \\
3 & $(1,3,5)$ & $(1 / 5,1 / 3,1 / 1)$ \\
5 & $(3,5,7)$ & $(1 / 7,1 / 5,1 / 3)$ \\
7 & $(5,7,9)$ & $(1 / 9,1 / 7,1 / 5)$ \\
9 & $(7,9,9)$ & $(1 / 9,1 / 9,1 / 7)$ \\
2 & $(1,2,4)$ & $(1 / 4,1 / 2,1 / 1)$ \\
4 & $(2,4,6)$ & $(1 / 6,1 / 4,1 / 2)$ \\
6 & $(4,6,8)$ & $(1 / 8,1 / 6,1 / 4)$ \\
8 & $(6,8,9)$ & $(1 / 9,1 / 8,1 / 6)$ \\
\hline
\end{tabular}

h. Determine the fuzzy synthetic extent with the following equation:

$$
\begin{aligned}
& \sum_{i=1}^{n} \sum_{j=1}^{m} M_{g i}^{j} \approx \\
& \left(\frac{1}{\sum_{i=1}^{n} \sum_{j=1}^{m} u_{i j}}, \frac{1}{\sum_{i=1}^{n} \sum_{j=1}^{m} m_{i j}}, \frac{1}{\sum_{i=1}^{n} \sum_{j=1}^{m} l_{i j}}\right)
\end{aligned}
$$

In the calculation of the fuzzy synthetic extent, the comparison of the fuzzy synthetic extent is calculated with the following equation:

$$
\mathrm{V}(\mathrm{M} 2 \geq \mathrm{M} 1)=\left\{\begin{array}{c|l}
1 & \text { if } \mathrm{m}_{2} \geq \mathrm{m}_{1} \\
0 & \text { if } \mathrm{I}_{1} \geq \mathrm{u}_{2} \\
\frac{u 1-u 2}{(m 2-u 2)-(m 1-l 1)} & \text { for other conditions }
\end{array}\right]
$$

i. Normalization

The next step is normalization which aims to determine the value of the weight vector for each criterion as below equation.

$$
d\left(A_{i}\right)=\frac{d\left(A_{i}\right)}{\sum_{i=1}^{n} d\left(A_{i}\right)}
$$

\section{Results and Discussions}

Based on the results of literature studies, interviews with academics and company experts, field observations, and data processing results, the following results were obtained presented below.

\subsection{Supply Chain Network}

In the supply chain network PT. XYZ contains three flows, namely the flow of products or goods, cost flow, and information flow flowing from upstream to downstream. The supply chain network of PT. XYZ is described in Figure 1 below.

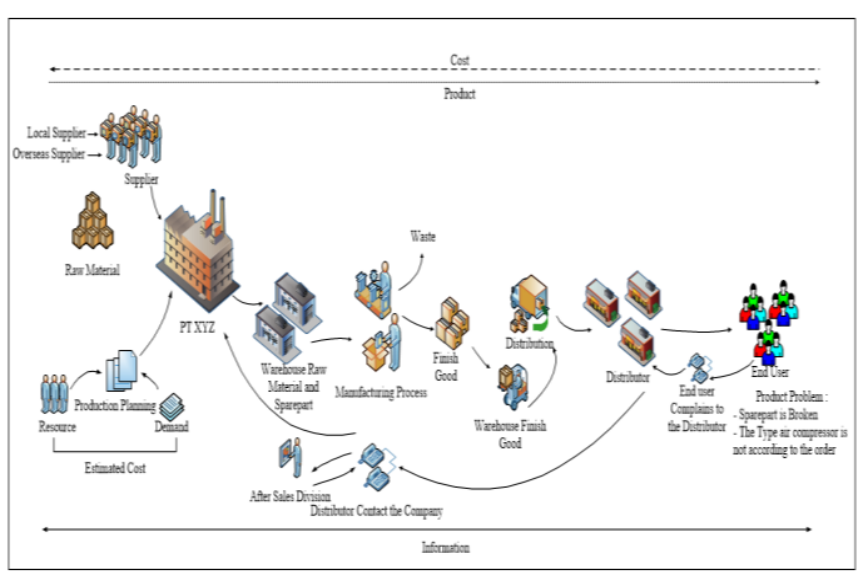

Figure 1. Supply Chain Network of PT. XYZ

In Figure 1. it can be seen that the supply chain network of PT. XYZ consists of local and overseas suppliers. Then enter the manufacturing process, the delivery process, until it reaches the end user.

\subsection{Determination of Risk Factors}

In the process of identifying risks [9] in the supply chain flow of air compressor Type L Unloading $1 / 4 \mathrm{HP}$ at PT. XYZ is to use risk factors obtained through literature studies and interviews. The following are the risk factors used for the risk identification process at PT. XYZ below. 
Table 5. Risk Factors

Risk Factors

Description

Supply risk or the risks contained in the

Supply Risk supply refer to the risks associated with the supply or supplier which have an impact on consumers and the company.

Demand risk is a potential risk in the

Demand Risk process of requesting or planning for air compressor products.

Manufacturing risk or manufacturing risk can be defined as the risk in Manufacturing Risk operations or in the production process that disrupts the flow of material or information in the supply chain.

\begin{tabular}{ll}
\hline Distribution Risk & $\begin{array}{l}\text { Distribution risk is a risk associated } \\
\text { with the process of distributing finished } \\
\text { products to consumers. }\end{array}$
\end{tabular}

\begin{tabular}{cl}
\hline Product Recovery & $\begin{array}{l}\text { Product recovery risk is a risk that can } \\
\text { occur when returning the damaged } \\
\text { Risk }\end{array}$
\end{tabular}

Information risk is a risk that can occur
in the flow of information in the supply
chain system.
chain system.

$\mathrm{K} 3$ and

Environmental Risk

$\mathrm{K} 3$ and Environmental risk are risks related to occupational safety and health as well as the company environment in the supply chain system.
The production target was not achieved

Incompatible input of material parts into the system

Equipment or machine problems

Spare parts having damaged

Making product parts not according

to specifications

sand hardness in the molding

process is imperfect

Manufacturing

Risk

spare parts it takes less

plate steel not up to specifications

The paint thickness on the product is

not suitable

Iron smelting process is not perfect

Reject products

The product packaging was

damaged during the shipping

E10

E11

E12

E13

E14

E15

E16

E17

E18

E19

Distribution process

Risk High shipping costs $\quad$ E21

Delay in the product delivery process

The occurrence of a product return $\quad$ E23

$\begin{array}{lll}\text { Product The occurrence of a spare part } & \text { E24 }\end{array}$

Recovery Risk

return

Delay in delivery of replacement

E25 products to consumers

Systems within the company are E26

less integrated

Information

the occurrence of miss

E27

communication between companies and consumers

$\begin{array}{clc}\begin{array}{c}\text { K3 and } \\ \text { Environmental } \\ \text { Risk }\end{array} & \begin{array}{l}\text { Occurrence of work accidents } \\ \text { The residual waste of production } \\ \text { pollutes the environment }\end{array} & \text { E28 } \\ & & \text { E29 } \\ \end{array}$
pollutes the environment
Based on Table 5. risk factors are used to identify risk events, among others supply risk, demand risk, manufacturing risk, distribution risk, product recovery risk, information risk, and $\mathrm{K} 3$ and Environmental risk.

\subsection{Risk Identification}

Based on the results of literature studies, interviews, and field observations. The 29 risk events identified [10] were described in Table 6. and Table 7. below

Table 6. Results of Risk Event Identification

\begin{tabular}{llc}
\hline Risk Factors & \multicolumn{1}{c}{ Risk Events } & Code \\
\hline \multirow{5}{*}{ Supply Risk } & Error item sent by supplier & E1 \\
& $\begin{array}{l}\text { The number of items sent did not } \\
\text { match the order }\end{array}$ & E2 \\
& $\begin{array}{l}\text { Increase in raw material prices } \\
\text { The raw material quality is not good }\end{array}$ & E3 \\
& Etock raw material ordered does not & E5 \\
& exist & E6 \\
\hline \multirow{2}{*}{ Lemand Risk } & Fate arrival of raw materials & E7 \\
& Delays in material procurement & E8
\end{tabular}

Table 7. Results of Causes of Risk Identification

\begin{tabular}{|c|c|c|}
\hline Risk Factors & Causes of Risk & Code \\
\hline \multirow{5}{*}{ Supply Risk } & $\begin{array}{l}\text { Lack of coordination between } \\
\text { suppliers and companies }\end{array}$ & A1 \\
\hline & $\begin{array}{l}\text { Inaccuracy of suppliers in } \\
\text { checking the amount of material }\end{array}$ & A2 \\
\hline & $\begin{array}{l}\text { Changes in currency exchange } \\
\text { rates }\end{array}$ & A3 \\
\hline & $\begin{array}{l}\text { Inaccuracy of suppliers in } \\
\text { checking material quality }\end{array}$ & A4 \\
\hline & $\begin{array}{l}\text { There is a production disruption } \\
\text { at the supplier }\end{array}$ & A5 \\
\hline \multirow{4}{*}{ Demand Risk } & $\begin{array}{l}\text { The occurrence of fluctuations } \\
\text { in product demand from } \\
\text { consumers }\end{array}$ & A6 \\
\hline & $\begin{array}{l}\text { Sudden change in production } \\
\text { plans }\end{array}$ & A7 \\
\hline & $\begin{array}{l}\text { There is a change in the } \\
\text { planning quantity when the } \\
\text { schedule is running }\end{array}$ & A8 \\
\hline & human error & A9 \\
\hline \multirow{2}{*}{$\begin{array}{c}\text { Manufacturing } \\
\text { Risk }\end{array}$} & $\begin{array}{l}\text { Lack of maintenance on the } \\
\text { machine }\end{array}$ & A10 \\
\hline & $\begin{array}{l}\text { Laying out spare parts by } \\
\text { stacking them }\end{array}$ & A11 \\
\hline
\end{tabular}




\begin{tabular}{|c|c|c|}
\hline & Operator error in using the tool & A12 \\
\hline & $\begin{array}{l}\text { The quality of the sand is not } \\
\text { good }\end{array}$ & A13 \\
\hline & $\begin{array}{l}\text { There is a problem in the } \\
\text { production of spare parts at the } \\
\text { supplier }\end{array}$ & A14 \\
\hline & $\begin{array}{l}\text { Operator error during the steel } \\
\text { cutting process }\end{array}$ & A15 \\
\hline & human error & A16 \\
\hline & $\begin{array}{l}\text { Operator inaccuracy when } \\
\text { setting the furnace temperature }\end{array}$ & A17 \\
\hline & Worker's negligence & A18 \\
\hline \multirow{3}{*}{$\begin{array}{l}\text { Distribution } \\
\quad \text { Risk }\end{array}$} & Not sturdy packaging used & A19 \\
\hline & Government regulations & A 20 \\
\hline & $\begin{array}{l}\text { Lack of transportation fleet } \\
\text { owned by the company }\end{array}$ & $\mathrm{A} 21$ \\
\hline \multirow{3}{*}{$\begin{array}{c}\text { Product } \\
\text { Recovery Risk }\end{array}$} & $\begin{array}{l}\text { The product that was sent did } \\
\text { not match the order }\end{array}$ & A22 \\
\hline & $\begin{array}{l}\text { Spare parts unable to function } \\
\text { or is damaged }\end{array}$ & A 23 \\
\hline & $\begin{array}{l}\text { There are problems on the } \\
\text { expedition }\end{array}$ & A24 \\
\hline \multirow{2}{*}{ Information Risk } & $\begin{array}{l}\text { Not yet accommodated several } \\
\text { divisions in the same system }\end{array}$ & $\mathrm{A} 25$ \\
\hline & $\begin{array}{l}\text { Lack of company-consumer } \\
\text { coordination }\end{array}$ & A26 \\
\hline \multirow{2}{*}{$\begin{array}{l}\mathrm{K} 3 \text { and } \\
\text { Environmental } \\
\text { Risk }\end{array}$} & $\begin{array}{l}\text { Lack of completeness of the } \\
\text { PPE used by workers }\end{array}$ & A27 \\
\hline & $\begin{array}{l}\text { There is no waste treatment } \\
\text { before the waste is disposed of }\end{array}$ & A 28 \\
\hline
\end{tabular}

Based on Table 6. And Table 7. above, it can be seen that 29 risk events were identified with 28 causes of risk.

\subsection{Risk Analysis}

At the risk analysis stage, data processing is carried out using the FMEA and Fuzzy-FMEA methods. The use of the FMEA method is only to determine the differences that occur before the data is processed using the fuzzy concept [11]. The results of data processing before and after are contained in Table 8 . below:

Table 8. Comparison Result between FMEA and Fuzzy-FMEA

\begin{tabular}{ccccccc}
\hline \multirow{2}{*}{ No. } & \multirow{2}{*}{ Code } & \multicolumn{2}{c}{ FMEA } & \multirow{2}{*}{ Code } & \multicolumn{2}{c}{ Fuzzy- FMEA } \\
& & RPN & Rank & & FRPN & Rank \\
\hline 1 & E1 & 265.84 & 1 & E11 & 700 & \\
\hline 2 & E19 & 210.13 & 2 & E14 & 700 & \multirow{2}{*}{2} \\
\hline 3 & E26 & 206.10 & 3 & E15 & 700 & \\
\hline 4 & E17 & 204.28 & 4 & E26 & 654 & 3 \\
\hline 5 & E4 & 203.44 & 5 & E13 & 640 & 4 \\
\hline 6 & E9 & 197.57 & 6 & E1 & 633 & 5 \\
\hline 7 & E3 & 194.56 & 7 & E5 & 627 & \multirow{2}{*}{7.5} \\
\hline 8 & E15 & 194.25 & 8 & E12 & 627 & \\
\hline 9 & E11 & 188.52 & 9 & E18 & 619 & 8 \\
\hline 10 & E7 & 185.94 & 10 & E27 & 617 & 9 \\
\hline 11 & E6 & 184.90 & 11 & E2 & 614 & \multirow{2}{*}{12}
\end{tabular}

\begin{tabular}{ccccccc}
\hline 13 & E8 & 183.23 & 13 & E20 & 614 & \\
\hline 14 & E23 & 180.13 & 14 & E28 & 613 & 13 \\
\hline 15 & E16 & 169.38 & 15 & E24 & 602 & 14 \\
\hline 16 & E12 & 158.10 & 16 & E22 & 601 & 15 \\
\hline 17 & E18 & 142.75 & 17 & E3 & 600 & \multirow{2}{*}{17.5} \\
\hline 18 & E20 & 140.22 & 18 & E8 & 600 & \\
\hline 19 & E2 & 134.13 & 19 & E7 & 585 & 18 \\
20 & E14 & 122.18 & 20 & E25 & 575 & 19 \\
\hline 21 & E10 & 121.48 & 21 & E10 & 558 & 20 \\
\hline 22 & E27 & 104.30 & 22 & E9 & 557 & \multirow{2}{*}{22.5} \\
\hline 23 & E25 & 103.63 & 23 & E23 & 557 & \\
\hline 24 & E13 & 71.82 & 24 & E6 & 552 & 23 \\
\cline { 1 - 2 } 25 & E28 & 71.82 & & E4 & 546 & \\
\cline { 1 - 5 } 26 & E24 & 66.84 & 25 & E16 & 546 & 25.5 \\
\hline 27 & E22 & 65.65 & 26 & E19 & 515 & 26 \\
29 & E21 & 58.66 & 27 & E21 & 513 & 27 \\
\hline
\end{tabular}

From the table above, it can be seen that the RPN (Risk Priority Number) and fuzzy-RPN (Fuzzy Risk Priority Number) values for each risk event. In calculations using the usual FMEA, the retang rank or rank of each RPN value is 1 28 , with the highest value of 265.84and the lowest value is 30.14 . While the results of calculations using fuzzy-FMEA, the largest value of fuzzyRPN (Fuzzy Risk Priority Number) is 700 and the lowest value is 337 .

\subsection{Risk Evaluation}

Risk evaluation aims to determine the priority risk of each risk event (risk event) wherein the risk mitigation action will be carried out. Risk evaluation is carried out on FRPN with the 3 largest ratings [12]. Where the decision making is based on the actual situation in the company as well as on the limited time available in conducting research.

The 3 largest FRPN ratings contain 5 risk events, namely lack of maintenance on the engine (E11), and hardness in the molding process is imperfect (E14), spare parts it takes less (E15), several divisions in the same system have not been accommodated (E26), and operator errors in using the tool (E13).

\subsection{Risk Mitigation Actions}

Risk mitigation action is a stage where it reduces or eliminates the possibility of certain risks or consequences [13]. Data processing in Table 9. the risk mitigation action section is using Fuzzy-AHP.

Based on calculations using Fuzzy-AHP, the following risk mitigation actions are proposed as on Table 9 below. 
Table 9. Proposed Risk Mitigation Actions

\begin{tabular}{|c|c|c|c|}
\hline No. & Causes of Risk & Weight & $\begin{array}{c}\text { Proposed Mitigation } \\
\text { Actions }\end{array}$ \\
\hline 1 & $\begin{array}{l}\text { not yet } \\
\text { accommodated } \\
\text { several divisions } \\
\text { in the same } \\
\text { system }\end{array}$ & 0.262 & $\begin{array}{l}\text { Creating a system that } \\
\text { can integrate all } \\
\text { divisions in the same } \\
\text { system } \\
\text { Improve coordination } \\
\text { between divisions }\end{array}$ \\
\hline 2 & $\begin{array}{l}\text { There is a } \\
\text { problem in the } \\
\text { production of } \\
\text { spare parts at the } \\
\text { supplier }\end{array}$ & 0,218 & $\begin{array}{l}\text { Looking for alternative } \\
\text { suppliers } \\
\text { Increase the availability } \\
\text { or number of safety } \\
\text { stock of spare parts }\end{array}$ \\
\hline 3 & $\begin{array}{l}\text { Lack of } \\
\text { maintenance on } \\
\text { the machine }\end{array}$ & 0.201 & $\begin{array}{l}\text { Check periodically } \\
\text { before and after the } \\
\text { machine is used } \\
\text { Make improvements in } \\
\text { machine maintenance }\end{array}$ \\
\hline 4 & $\begin{array}{l}\text { Operator error in } \\
\text { using the tool }\end{array}$ & 0.168 & $\begin{array}{l}\text { Provide training to } \\
\text { operators or employees } \\
\text { Provide SOP for the use } \\
\text { of each tool }\end{array}$ \\
\hline 5 & $\begin{array}{l}\text { The quality of } \\
\text { the sand used is } \\
\text { not good }\end{array}$ & 0.152 & $\begin{array}{l}\text { Check the quality of the } \\
\text { sand } \\
\text { Perform regular sand } \\
\text { changes after use }\end{array}$ \\
\hline
\end{tabular}

\section{Conclusion}

Based on the research results obtained 29 identified risk events in the supply chain flow of Air compressor Type L Unloading 1/4 HP. Furthermore, for risk events that become priority are 5 risk events, among others lack of maintenance on the engine (E11), sand hardness in the molding process is imperfect (E14), spare parts it takes less (E15), several divisions in the same system have not been accommodated (E26), and operator errors in using the tool (E13). Then for mitigation actions for each risk event is to create a system that can integrate all divisions in the same system, and improve coordination between divisions. look for other alternatives, and increase the availability or amount of safety stock. carry out regular checks before and after the machine is used and make improvements to machine maintenance. provide training to operators or employees, and provide SOPs for the use of each tool. check the quality of the sand and replace the sand regularly.

\section{References}

[1] Pujawan, I. N. (2010). Supply Chain Management, $2^{\text {nd }}$ Ed. Guna Widya Surabaya.

[2] Natalia, C., Astuario, R. (2015). Implementation of the Green SCOR Model for Managing Green Supply Chain Performance. Metric Journal. Vol 16 No 2: 97 - 106.

[3] Handayani, D. I. (2016). A Review: Potential Risks in Supply Chain Risk Management. Industrial Spectrum. Vol 14 No 1: 25 - 35.

[4] Sari, Y. K., Santoso, P. B., Sari, R. A. (2015.) Supply Chain Risk Analysis at PT Kasin Malang Using Fuzzy Analytical Hierarchy Process (Fuzzy-AHP) Method. Journal of Industrial Systems Engineering and Management. Vol 3 No 2: 280-290.

[5] Pontotoring, P.P., Andika, A. (2019). Risk Analysis of Employees of Retail Companies with the FMEA Method and Fishbone Diagram. Journal of Scientific Studies. Vol 19 No 1: 1-7.

[6] Winanto, E. A., Santoso, I. (2017). Integration of Fuzzy FMEA and AHP Methods in the Analysis and Mitigation of Onion Supply Chain Risk. Journal of Industrial Technology \& Agricultural Products. Vol 22 No 1: 21 - 32.

[7] Kumru, M., Kumru, P. Y. (2013). Fuzzy FMEA Application to Improve Purchasing Process in a Public Hospital. Elsevier Journal. Vol 13 No 1: $721-733$.

[8] Ganguly, K. K., Kumar, G. (2019). Supply Chain Risk Assessment: A Fuzzy AHP Approach. Operations and Supply Chain Management. Vol 12 No 1: 1 - 13.

[9] Bahauddin, A., Minata, Arina. (2015) Analisis dan Strategi Penanganan Risiko Supply Chain Pada PT. Batik Banten Indonesia Menggunakan AHP dan FMECA. Universitas Ageng Tirtayasa, Cilegon.

[10] Mangla, S. K., Kumar, P. Barua, M.K. (2016). An Integrated Methodology of FTA and Fuzzy AHP for Risk Assessment in Green Supply Chain. International Journal Operational Research. Vol 25 Zero 1: 77 - 99.

[11] Moktadir, M. A., Ali S., Mangla, S. K., Sharmy T. Luthra S., Mishar N., Garza-Reyes, Arturo J. (2017). Decision Modeling for Evaluating Risks in Pharmaceutical Supply Chains. DOI 10.1108 / IMDS-10-2017-0465. Avalilable from: URL: http: // hdl. Handle.net/10545/622995. 
[12] Ridwan, A., Trenggonowati, D. L., Parida, V. (2019). Usulan aksi mitigasi risiko rantai pasok halal pada UKM tahu Bandung Sutra menggunakan metode house of risk. Journal Industrial Servicess, vol. 5, no. 1, pp. 112-120.
[13] Qianlei, L. 2012. The Study on the Risk Management of Agricultural Products Green Supply Chain Based on Systematic Analysis. Second International Conference on Business Computing and Global Informatization Department of Engineering Science Shanghai University. Shanghai 12-14 October 2012. Pages 250 - 253. 